\title{
Loss of genetic diversity through spontaneous colonization in the bog fritillary butterfly, Proclossiana eunomia (Lepidoptera: Nymphalidae) in the Czech Republic
}

\author{
Gabriel NÈVE ${ }^{1 *}$, Alois PAVLÍČKOO ${ }^{2}$ and Martin KONVIČKA ${ }^{3,4}$ \\ ${ }^{1}$ Institut Méditerranéen d'Ecologie et Paléoécologie, UMR CNRS 6116, Case 36, Université de Provence, 3 Place Victor Hugo, \\ F-13331 Marseille Cedex 3, France; e-mail: gabriel.neve@univ-provence.fr. \\ ${ }^{2}$ Science and Research Department, National Park Šumava, 1. máje 260, CZ-385 01 Vimperk, Czech Republic; \\ e-mail: alois.pavlicko@npsumava.cz \\ ${ }^{3}$ Biology Centre ASCR, Institute of Entomology, Branišovská 31, CZ-370 05 České Budějovice, Czech Republic; \\ e-mail:konva@entu.cas.cz \\ ${ }^{4}$ Faculty of Science, University of South Bohemia, CZ-370 05 České Budějovice, Czech Republic
}

Key words. Allozyme electrophoresis, conservation, genetic polymorphism, Lepidoptera, mountain habitats, range expansion, relict population

\begin{abstract}
The butterfly Proclossiana eunomia (Lepidoptera: Nymphalidae) was discovered at a single locality in the Czech Republic in 1963. Until the 1980s, it was known from a restricted area, from which it spontaneously expanded during the 1980 s to other localities up to $23 \mathrm{~km}$ from the source population. Samples were collected in 2002 from the source and ten other populations, totalling 274 specimens. All samples were analysed by electrophoresis for four polymorphic loci. Mean heterozygosity decreased with distance from the source population; this suggested a process of stepping stone colonization, involving the loss of rare alleles along the way. The populations close to the source population (less then ca. $15 \mathrm{~km}$ ) retain a similar heterozygosity, whereas populations further away have a much reduced heterozygosity. Such a pattern of genetic differentiation and founder effect within a region is typical of specialized species with relatively low dispersal ability. The high level of genetic polymorphism found in the Šumava populations suggests that populations of this northern species in temperate-zone mountains are not just outposts of otherwise huge northern distribution, but represent genuine phylogeographic refugia. Survival of such species depends on the survival of the source population and of a sufficiently dense network of habitat patches.
\end{abstract}

\section{INTRODUCTION}

Colonization and migration events are key processes in metapopulation dynamics, ensuring the long term survival of species within a shifting range of habitat patches (Hanski, 1999). The resulting spatial structure of the metapopulations will eventually depend on the amount of movement among the patches. If individuals move between populations at a high rate, all local populations within a region would be considered as part of a single large population. Under a certain threshold of movement, populations tend to differentiate and colonies inhabiting individual patches begin to differentiate genetically from each other, which is manifested by a significant fixation index (Wright's $F_{S T}$ ) (Gilpin, 1991; Barton \& Whitlock, 1997).

Due to natural or artificial causes, many species tend to survive in refugium patches, while they go extinct elsewhere (e.g. Habel \& Assmann, 2009). Eventually, as the conditions near the refugium patches improve, the refugial population may serve as source of colonists for colonising newly appearing patches (e.g. Summerville, 2008). Some of these newly colonized habitat patches may in turn become sources of new propagules, leading to a stepping stone pattern of the species' range expansion. In terms of genetic structure, frequent migration events among sets of occupied patches result in low to nonexistent population differentiation. In contrast, if colonization involves only few individuals, founder effects becomes apparent and the populations furthest from the original colonization source will have an impoverished genetic makeup, detectable as lower heterozygosity (Eckert et al., 2008).

The bog fritillary butterfly, Proclossiana eunomia (Esper, 1799) (Nymphalidae) is a specialist of wet meadows and bogs, displaying relict distribution in Central and Western Europe (Weiss, 1972; Nève et al., 1996; Descimon et al., 2001). Within this relict range, it is threatened by habitat loss or mismanagement (Schtickzelle et al., 2007). Extensive studies of its demographic and genetic population structure, carried out in Belgium, Finland and France (Schtickzelle et al., 2006), revealed a high rate of movement among local colonies and hence a low genetic differentiation within landscapes (Nève et al., 2008). An extreme case was the study carried out in Morvan, France, where the species was introduced in 1970 and 1974 (Descimon, 1976) into a previously unoccupied region. A few released individuals quickly gave rise to a viable metapopulation, expanding at a rate of ca. 0.4 $\mathrm{km} /$ year (Nève et al., 1996). However, even this successful colonization of novel area caused some genetic 


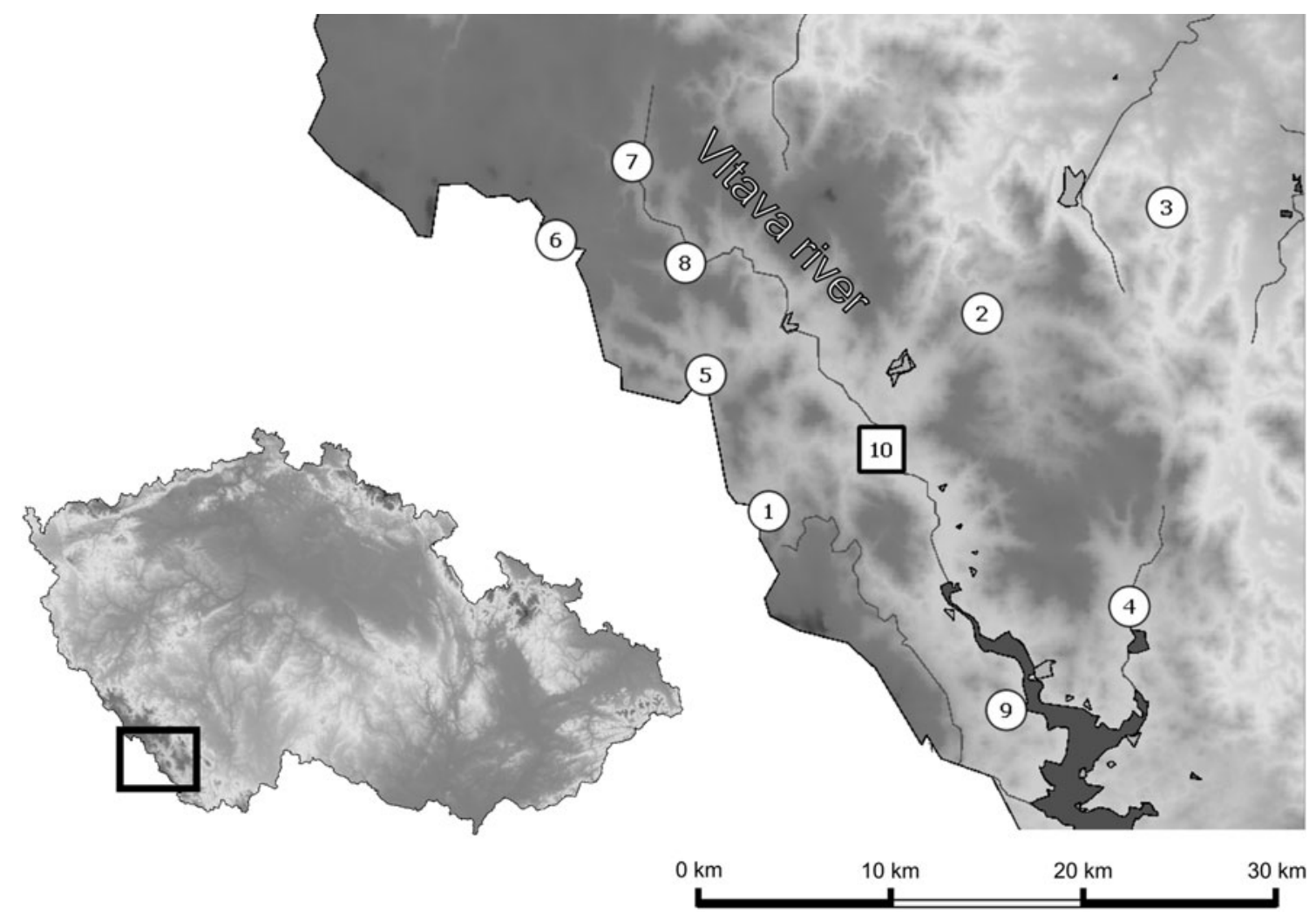

Fig. 1. Map of the study area, showing its location in the Czech Republic (left) and that of the sampled populations of Proclossiana eunomia. Population 10 (white square) is the original refuge population in the Vltava river valley (Mrtvý luh bog), whereas the remaining populations (circles) were established via spontaneous expansion of the butterfly.

differentiation along the river system, suggesting a stepping-stone colonization process, with some genetic variation lost on the way (Barascud et al., 1999).

In this paper, we analyse another case of colonization by $P$. eunomia. In contrast to the French case, this species is native to the Sumava Mts, Czech Republic. It was, however, completely unknown in this area until 1963, when it was discovered in the Mrtvý luh reserve, a large (ca. 1250 ha) system of bogs and wet meadows along the upper Vltava river (Fig. 1) (Weiss, 1966, 1967). In the following decade, it was considered an extreme rarity, known from Vltava valley only, despite increased interest in surveying the broader area (e.g. Ebenhöh, 1972; Weiss, 1972). A gradual expansion of distribution area since the early 1980s was observed by one of us (AP, who is a local resident). Up till now the number of occupied localities has increased by factor 24, the current distribution area now covers ca $450 \mathrm{~km}^{2}$ and the most distant colonies are situated ca. $25 \mathrm{~km}$ (aerial distance) from the source population (Pavlíčko, 1996a, b; Beneš et al., 2002). This increase is unlikely to be an artefact of improved recording, because the number of known sites of the cooccurring butterfly Boloria aquilonaris (Stichel, 1908) has increased only by a factor of seven. More likely, it is a genuine expansion related to habitat changes following abandonment of grasslands across Šumava Mts. The region was densely settled by ethnic Germans prior to World War II and these people used the grasslands for hay production and pasture, meticulously maintaining drainage systems. Abandonment of the grasslands after the war led to successional changes; many of the meadows became dominated by tussocky grasses (e.g. Deschampsia caespitosa), sedges (e.g. Carex brizoides) and the bistort, which increased the resources available for P. eunomia (Pavlíčko, 1996a; Schtickzelle et al. 2007). See Krahulec et al. (1997) for a description of a similar development of vegetation in another mountain range.

Tracking the expansion using allozyme electrophoresis allowed us to asses the genetic effects of a spontaneous colonization from a presumably large and long-lived source population. Specifically, we asked the following questions. (i) Did the spontaneous establishment of daughter populations up to $25 \mathrm{~km}$ from the original population lead to founder effect or genetic drift? (ii) Has the colonization process already lead a discernible geographic structure, with an isolation by distance effect?

\section{MATERIAL AND METHODS}

\section{Study species}

Proclossiana eunomia is a Holarctic species, distributed from Europe through northern Asia to Alaska, Canada and Rocky Mountains states of USA (Tuzov \& Bozano, 2006; Nève et al., 2008). It is the only species of the genus Proclossiana Reuss, 1921, sometimes considered as a subgenus of Boloria Moore, (1900), together with its sister genus Clossiana Reuss, 1920 (Simonsen, 2005, 2006). It exhibits a relict distribution limited to high altitudes in temperate Europe. Apart from the Sumava Mts, it includes the Pyrenees, the Ardennes, the Schwarzwald 
TABLE 1. Allele frequencies across populations. The populations are numbered as in Fig. 1. Data are also provided for Belgium populations, as these were used as an outgroup in the UPGMA analysis.

\begin{tabular}{|c|c|c|c|c|c|c|c|c|c|c|c|c|c|c|}
\hline \multirow{2}{*}{$\begin{array}{l}\text { Popula- } \\
\text { tion no. }\end{array}$} & \multirow{2}{*}{ Locality } & \multirow{2}{*}{$\begin{array}{c}\text { Sample } \\
\text { size }\end{array}$} & \multicolumn{3}{|c|}{ PGI } & \multicolumn{2}{|c|}{ PGM } & \multicolumn{2}{|c|}{$\mathrm{AK}$} & \multicolumn{2}{|c|}{ GOT } & \multicolumn{3}{|c|}{ 6PGD } \\
\hline & & & $\mathrm{a}$ & $\mathrm{b}$ & $\mathrm{c}$ & $\mathrm{a}$ & $\mathrm{b}$ & $\mathrm{a}$ & $\mathrm{b}$ & $\mathrm{a}$ & $\mathrm{b}$ & $\mathrm{a}$ & $\mathrm{b}$ & $\mathrm{c}$ \\
\hline 1 & Nové Údolí & 16 & 0.906 & 0.094 & 0.000 & 1.000 & 0.000 & 0.125 & 0.875 & 0.156 & 0.844 & 0.094 & 0.688 & 0.219 \\
\hline 2 & Blažejovice & 32 & 0.938 & 0.063 & 0.000 & 1.000 & 0.000 & 0.281 & 0.719 & 0.188 & 0.812 & 0.203 & 0.797 & 0.000 \\
\hline 3 & Frantoly - jih & 14 & 1.000 & 0.000 & 0.000 & 1.000 & 0.000 & 0.071 & 0.929 & 0.321 & 0.679 & 0.000 & 1.000 & 0.000 \\
\hline 4 & Otice & 28 & 1.000 & 0.000 & 0.000 & 1.000 & 0.000 & 0.143 & 0.857 & 0.143 & 0.857 & 0.232 & 0.661 & 0.107 \\
\hline 5 & Stráženská slatina & 27 & 0.944 & 0.056 & 0.000 & 1.000 & 0.000 & 0.130 & 0.870 & 0.019 & 0.981 & 0.093 & 0.889 & 0.019 \\
\hline 6 & Knížecí Pláně & 33 & 0.955 & 0.045 & 0.000 & 1.000 & 0.000 & 0.015 & 0.985 & 0.015 & 0.985 & 0.015 & 0.985 & 0.000 \\
\hline 7 & Borová Lada & 22 & 0.909 & 0.091 & 0.000 & 1.000 & 0.000 & 0.045 & 0.955 & 0.000 & 1.000 & 0.045 & 0.955 & 0.000 \\
\hline 8 & Zahrádky - Polka & 27 & 0.963 & 0.037 & 0.000 & 1.000 & 0.000 & 0.037 & 0.963 & 0.000 & 1.000 & 0.074 & 0.926 & 0.000 \\
\hline 9 & $\begin{array}{l}\text { Hamr - Zadní } \\
\text { Zvonková }\end{array}$ & 20 & 1.000 & 0.000 & 0.000 & 1.000 & 0.000 & 0.450 & 0.550 & 0.025 & 0.975 & 0.350 & 0.650 & 0.000 \\
\hline 10 & Mrtvý luh - soutok & 37 & 0.946 & 0.054 & 0.000 & 1.000 & 0.000 & 0.216 & 0.784 & 0.054 & 0.946 & 0.405 & 0.595 & 0.000 \\
\hline 11 & Nové Údolí & 18 & 0.972 & 0.028 & 0.000 & 1.000 & 0.000 & 0.139 & 0.861 & 0.194 & 0.806 & 0.206 & 0.794 & 0.000 \\
\hline Mean & & & 0.958 & 0.042 & 0.000 & 1.000 & 0.000 & 0.150 & 0.850 & 0.101 & 0.899 & 0.156 & 0.813 & 0.031 \\
\hline$F_{S T}$ & & & 0.003 & & & 0.000 & & 0.099 & & 0.095 & & 0.123 & & \\
\hline $10(1994)$ & & & 0.972 & 0.028 & 0.000 & 1.000 & 0.000 & 0.208 & 0.792 & 0.194 & 0.806 & 0.194 & 0.597 & 0.208 \\
\hline Belgium & & & 0.997 & 0.000 & 0.003 & 0.307 & 0.693 & 0.448 & 0.552 & 0.000 & 1.000 & 0.731 & 0.255 & 0.014 \\
\hline
\end{tabular}

Mts in southern Germany, a few spots in the eastern Alps (Verity, 1950; Reichl, 1992), and the Stara Planina Mts in Bulgaria (Abadjiev, 1995) and Serbia (Jakšić et al., 2007). The habitats in Central Europe are peat bogs and neglected damp grasslands with a high cover of the larval host plant, the bistort Polygonum bistorta; the bistort is also the main nectar source. In the Šmava Mts, the butterfly is single-brooded, with adult flight from early June until early July. Males locate females by active patrolling (Baguette et al., 1996), eggs are laid singly or in small batches, solitary larvae spend days hidden in host plant foliage and feed nocturnally. After overwintering, the larvae often bask on dry grass tussocks. Pupa is a short-lived stage, hanging on stems of herbaceous plants and grasses (Havel, 1970).

\section{Sampling, electrophoresis and data analysis}

In June 2002, a total of 274 specimens were collected from 11 populations throughout the whole area now occupied by the species in the Czech Republic (Fig. 1). An earlier sample of 36 specimens from population 10 was obtained in June 1994. The specimens were deep frozen on the day of capture and kept frozen at $-80^{\circ} \mathrm{C}$ until analysis. Each sampled location was further characterized by area of suitable habitat, habitat quality (a three point system, 3 indicates presence of a rich bistort supply within tussocky grasslands, 1 indicates few bistorts and no tussocks), and distance from the source population.

Isozyme electrophoreses on cellulose acetate were carried out on the sampled specimens, according to standard techniques (Richardson et al., 1986; Hebert \& Beaton, 1993; Nève et al., 2000). Six loci were scored for all individuals: phosphoglucomutase (PGM), phosphoglucoisomerase (PGI), glutamate oxaloacetate transaminase (GOT), 6-phosphogluconis deshydrogenase (6PGD), adenylate kinase (AK) and mannose phosphate isomerase (MPI).

Alleles were named from the slowest to the fastest detected in the whole sample. PGM is monomorphic regionally (whereas it is polymorphic in all other populations studied in Europe; Nève et al., 2008), PGI, GOT and AK showed two alleles each, and 6PGD three. Other populations of $P$. eunomia have also been investigated, notably from the Ardennes, Morvan, Pyrenees, and
Asturias mountains (Nève et al., 2008), and a single population from the Stara Planina (Bulgaria). In addition to the mentioned loci, all these populations were also tested for polymorphism in the G6PDH, HBDH, AAT (2nd loci), and $\alpha$ GPDH (which all proved monomorphic in the Czech sample).

Hardy-Weinberg equilibrium, population differentiation (Raymond \& Rousset, 1995), the fixation index $F_{S T}$ (both global and pairwise), and the inbreeding coefficient $F_{I S}$ were estimated using Genepop'007 (Rousset, 2008). The expected and the observed heterozygosities were computed using $Q$ as the probability of getting identical pairs of alleles; $1-Q_{\text {intra }}$ gives the genetic diversity within individuals (i.e. the observed heterozygosity when averaged over individuals within a population) and $1-Q_{\text {inter }}$ gives the genetic diversity within populations (i.e. the expected heterozygosity) (Rousset, 2008). Relevance of groups of populations were tested using hierarchical $F$ statistics in Hierfstat (Goudet, 2005). In order to study the genetic relationship between the populations in 2002, the Cavalli cord genetic distance between all pairs of populations were computed. A bootstrap on loci was performed with SEQBOOT (Felsenstein, 1993) and a consensus tree constructed using only the branches with an occurrence in more than $50 \%$ of the trees obtained by bootstrapping. The dendrogram was constructed with UPGMA using Belgian populations (cf. Nève et al., 2000) as an outgroup.

Using $F_{S T}$ as a measure of distance between population pairs, a map was reconstructed by multidimentional scaling (cmdscale function, R Development Core Team, 2004). This map was then subjected to a $45^{\circ}$ rotation to match it with the orientation of the geographical map.

Isolation by distance was assessed using the relationship between the logarithm of the geographical distance and the logarithm of the estimated number of migrants between populations $(\mathrm{Nm})$, as estimated by

$$
N m \approx \frac{1}{4}\left(\frac{1}{F_{S T}}-1\right)
$$

(Slatkin, 1993).

Neighbourhood area may then be estimated by the intercept of the function of the pairwise $F_{S T}=a+b /(4 x+1)$, where $x$ is 
TABLE 2. Population genetic differentiation probabilities, according to a Fisher's exact test across all loci per pair of populations (Raymond \& Rousset, 1995; Rousset, 2008).

\begin{tabular}{|c|c|c|c|c|c|c|c|c|c|c|c|}
\hline & 1 & 2 & 3 & 4 & 5 & 6 & 7 & 8 & 9 & 10 & 11 \\
\hline 1 & & & & & & & & & & & \\
\hline 2 & $*$ & & & & & & & & & & \\
\hline 3 & NS & $* *$ & & & & & & & & & \\
\hline 4 & NS & $* *$ & $* *$ & & & & & & & & \\
\hline 5 & NS & $* *$ & $* *$ & $*$ & & & & & & & \\
\hline 6 & $* * *$ & $* * *$ & * & $* * *$ & $\mathrm{NS}$ & & & & & & \\
\hline 7 & $* *$ & $* * *$ & $* *$ & $* * *$ & $\mathrm{NS}$ & NS & & & & & \\
\hline 8 & $* *$ & $* * *$ & $* *$ & $* * *$ & $\mathrm{NS}$ & NS & $\mathrm{NS}$ & & & & \\
\hline 9 & $* * *$ & $* *$ & $* * *$ & $* * *$ & $* *$ & $* * *$ & $* * *$ & $* * *$ & & & \\
\hline 10 & $* * *$ & $*$ & $* * *$ & $* *$ & $* *$ & $* * *$ & $* * *$ & $* * *$ & NS & & \\
\hline 11 & NS & NS & NS & NS & NS & $* * *$ & $* *$ & $* *$ & $* *$ & NS & \\
\hline
\end{tabular}

10 (1994) $\mathrm{NS} * * * * \mathrm{NS} * * * * * * * * * * * * * * * * * * \mathrm{NS}$

$* P<0.05, * * P<0.01, * * * P<0.001$, NS - not significant.

the geographical distance between populations, and $a$ and $b$ the fitted parameter values (Porter \& Geiger, 1995).

This approach works on the hypothesis of an island model, where migrants may move between any pair of populations, a hypothesis rarely met in field situations (Whitlock \& McCauley, 1999). However, this approach still proved useful, especially in cases where dispersal power is large and population size small (Rousset, 2004), providing the estimates of $\mathrm{Nm}$ are not regarded as accurate and only used for comparative purposes (Neigel, 2002).

\section{RESULTS}

Five of the six loci studied proved polymorphic; mannose phosphate isomerase (MPI), which proved to be polymorphic in the study area, was unfortunately not scorable for some populations; it was therefore not used in the present analyses.

Most of the populations investigated showed significant polymorphism (Table 1). The global $F_{S T}$ was estimated at 0.0981 . Values of pairwise $F_{S T}$ ranged from -0.0076 (between populations 7 and 8) to 0.1576 (between popu-

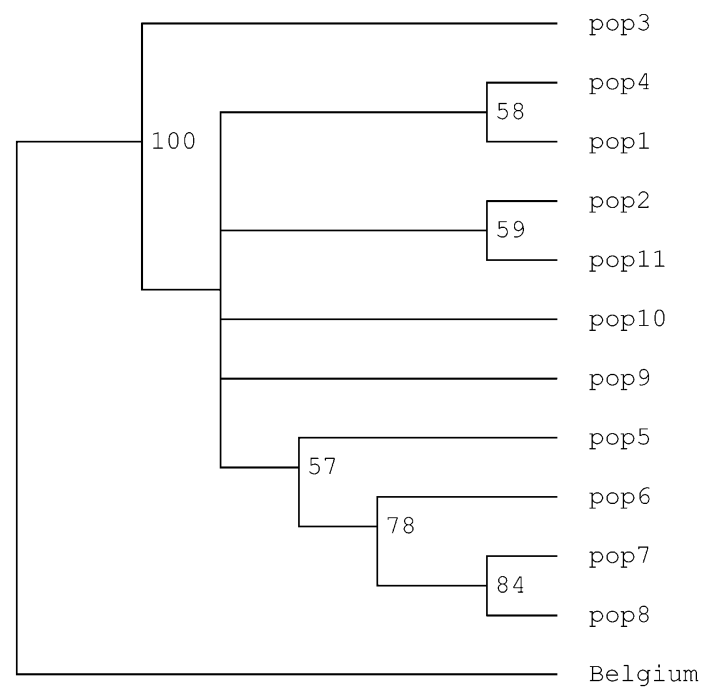

Fig. 2. Dendrogram of genetic similarity across populations, using Cavalli cord genetic distance. Bootstrap was performed on the loci and only forks indicated in more than $50 \%$ of the obtained trees were retained. This consensus dendrogram was constructed using Felsenstein's CONSENSE program, with UPGMA grouping, using Belgian populations as an outgroup. Figures indicate percentage of dendrograms that contained that particular branching.

lations 1 and 6). In the majority of cases the populations differed from each other (Table 2). Between 1994 and 2002, population 10 showed significant changes in allelic frequencies for loci Got $(P=0.0015)$ and $6 p g d(P<$ $0.001)$, but not for loci Pgi $(P=0.67)$ and $A k(P>0.99)$. The allele apparently lost in the source population between 1994 and 2002 (allele C of locus 6pgd) was still present in populations 1,4 , and 5 (Table 1). Populations 1 and 11 show poor differentiation, according to Fischer's exact test (Raymond \& Rousset, 1995), from the others, probably due to the small size of the samples (16 and 18 specimens, respectively). Populations 5 to 8 clearly form a distinct cluster of populations within the region $(G=$ 115.70; $P<0.01)$.

TABLE 3. Mean allelic richness, expected $\left(1-Q_{\text {inter }}\right)$ and observed (1- $\left.Q_{\text {intra }}\right)$ heterozygosities, averaged over loci per sample, and Weir \& Cockerham's (1984) FIS per locus and per population. Calculations performed using Genepop007 (Rousset, 2008).

\begin{tabular}{ccccccccccccc}
\hline & \multicolumn{10}{c}{ Populations } \\
\cline { 2 - 13 }$y$ & 1 & 2 & 3 & 4 & 5 & 6 & 7 & 8 & 9 & 10 & 11 & $10(1994)$ \\
\hline $\begin{array}{c}\text { Mean allelic } \\
\text { richness }\end{array}$ & 2.000 & 1.781 & 1.400 & 1.797 & 1.782 & 1.418 & 1.547 & 1.500 & 1.540 & 1.743 & 1.756 & 1.926 \\
$1-Q_{\text {inter }}$ & 0.233 & 0.233 & 0.119 & 0.201 & 0.116 & 0.036 & 0.069 & 0.057 & 0.206 & 0.208 & 0.192 & 0.271 \\
$1-Q_{\text {intra }}$ & 0.200 & 0.269 & 0.100 & 0.193 & 0.104 & 0.036 & 0.073 & 0.059 & 0.170 & 0.205 & 0.157 & 0.267 \\
\hline$F_{\text {IS }}$ Pgi & -0.071 & -0.051 & NA & NA & -0.040 & -0.032 & -0.077 & -0.020 & NA & -0.043 & 0.000 & -0.145 \\
$F_{I S}$ Pgm & NA & NA & NA & NA & NA & NA & NA & NA & NA & NA & NA & NA \\
$F_{I S}$ Ak & -0.111 & -0.066 & -0.040 & 0.143 & 0.198 & 0.000 & -0.024 & -0.020 & 0.016 & 0.057 & 0.329 & -0.250 \\
$F_{I S}$ Got & -0.154 & -0.216 & 0.217 & -0.149 & 0.000 & 0.000 & NA & NA & 0.000 & 0.482 & -0.214 & 0.085 \\
$F_{\text {IS } \text { fpgd }}$ & 0.494 & -0.240 & NA & 0.086 & 0.097 & 0.000 & -0.024 & -0.061 & 0.363 & -0.108 & 0.484 & 0.124 \\
\hline$F_{\text {IS } \text { All loci }}$ & 0.141 & -0.153 & 0.157 & 0.042 & 0.106 & -0.016 & -0.050 & -0.040 & 0.174 & 0.012 & 0.179 & 0.015 \\
\hline
\end{tabular}

NA - not applicable (i.e. only one allele). 


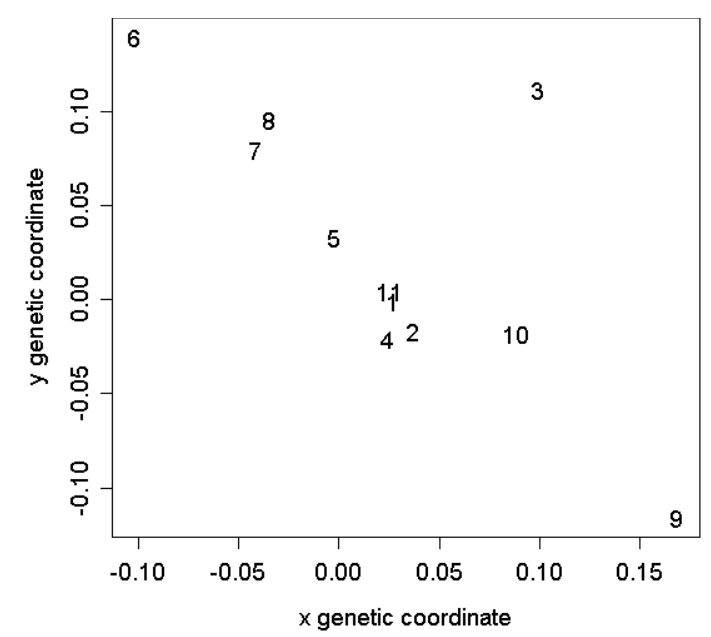

Fig. 3. Multidimensional scaling map based on $F_{S T}$ between pairs of populations. The resulting coordinates were then subjected to a $45^{\circ}$ rotation to obtain an orientation similar to the geographical map.

The consensus dendrogram of population differentiation (Fig. 2) suggests three groups of populations, which were confirmed by the Hierfstat $G$ test $(G=149.05 ; P=$ $0.01)$ : (i) those close to the to the expansion source $(1,2$, $4,9,10,11$ ), (ii) a set of populations closely connected with each other (5 to 8) and (iii) a genetically impoverished isolated population (population 3) in the northeastern part, with low heterozygosity estimates (3.6 to $11.6 \%$ ). The population within the second group (populations 5 to 8 ) are linked by dispersing individuals, as the genetic differentiation between any two of them was small. The map obtained by multidimensional scaling (Fig. 3) was very close to the geographical map, highlighting the isolation of population 3 .

Heterozygosity decreases significantly with distance between the source population (10) and the nine other populations ( $t=-3.85,8 d f, P=0.005$, Fig. 4$)$, whereas neither habitat area nor habitat quality nor their interac-

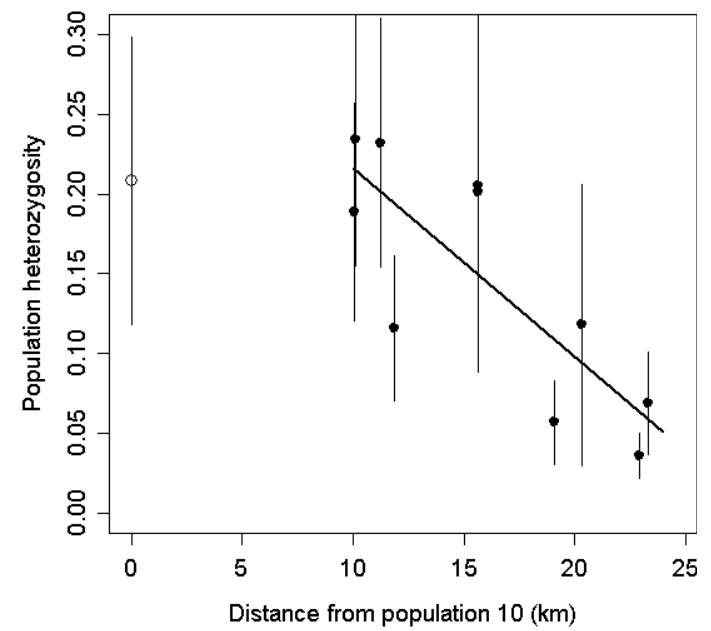

Fig. 4. Estimated heterozygosity as a function of the distance from the source population (open circle: population 10, Mrtvý Luh), vertical bars indicate the standard errors of the estimate.

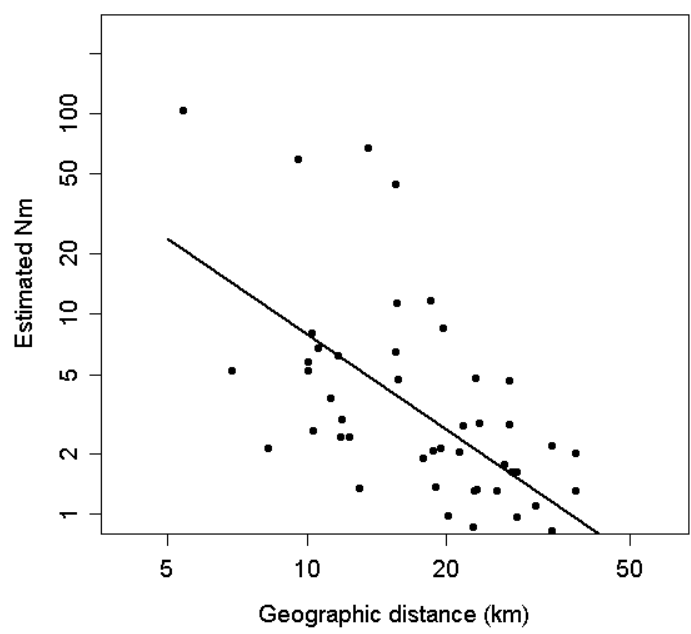

Fig. 5. Estimated numbers of migrants per generation between pairs of populations $(\mathrm{Nm})$ plotted against the distance in $\mathrm{km}$ between populations (both in logarithmic scale). $\log (\mathrm{Nm})$ $=5.72-1.58 \log ($ dist $), P<0.001$ (Mantel test between $F_{S T}$ and distance matrices).

tion had an impact on heterozygosity (all $P>0.5$ ). The populations with the lowest heterozygosities were the four to the northwest $(5,6,7$, and 8$)$ and population 3 isolated in the north east (Table 3 ).

None of the populations deviated significantly from the Hardy-Weinberg equilibrium (Table 3 ). Isolation by distance was detected, with a highly significant relationship (Mantel test, $P<0.001$ ) between the logarithm of the geographical distance between populations and the logarithm of the estimated number of migrants between populations (Fig. 5). The relationship between the pairwise $F_{S T}$ and the geographical distances $x$ between populations was given by the relationship $F_{S T}=0.176+4.510 /(4 x+1)(t=$ $-5.106,53 \mathrm{df}, P<0.001)$, giving an estimate of neighbourhood size of $6.152 \mathrm{~km}$.

On a broader context, the Šumava system is situated midway between the Balkan range and the Ardennes. Its level of polymorphism, estimated as the mean number of alleles per investigated locus, is lower than that for the Stara Planina Mts (2.1 alleles/locus) and Pyrenees (2.0 alleles/locus), and similar to that found in the Asturias (1.7 alleles/locus). The populations from the Ardennes (1.5 alleles/locus) have a lower polymorphism. Sixteen of the 17 alleles found in the Šmava system were found in the Pyrenees and only 12 in the Stara Planina populations. One allele (of 6PGD) was found only in the Sumava populations.

\section{DISCUSSION}

Despite the rather recent expansion from a refugial area, a clear genetic impact of colonization is apparent in the Šumava mountains metapopulation of Proclossiana eunomia. The within-population heterozygosity decreases with distance from the expansion source, which denotes a strong impact of colonization by stepping stones, with multiple founding effects, rescuing the allele apparently lost by population 10 between 1994 and 2002. In contrast to the experimentally released $P$. eunomia population in 
France (i.e., Morvan, cf. Barascud et al., 1999), the Šmava populations exhibit a very significant isolation by distance effect, as observed for many resident butterfly species (Nève, 2009). Moreover, the Sumava populations harbour a higher genetic diversity than the intensively studied $P$. eunomia populations in the Ardennes region, and the same holds true for $P$. eunomia populations in other European mountain ranges such as the Asturias, Pyrenees, and Stara Planina (Descimon et al., 2001; Nève et al., 2008).

Compared with the other studies on the same species in four other European areas (i.e. Ardennes, Morvan, Pyrenees, and Asturias), the isolation by distance effect is much stronger in the Sumava system: the slope of the $\log (\mathrm{Nm})$ $\log ($ dist $)$ relationship is 1.58 , compared with 0.948 in Asturias, 0.656 in Pyrenees, 0.0073 in Ardennes, and no significant pattern in Morvan. The strong isolation by distance observed here is probably the result of multiple founder effects. The expansion began from a relatively large and polymorphic populations, but the founders of progressively distant peripheral populations have repeatedly originated from marginal populations that were themselves already subject to high genetic drift (Excoffier \& Ray, 2008). Contrary to this, the artificially established Morvan population originated from only 18 females from a single Ardennes population (Descimon, 1976). The transfer itself represented a strong bottleneck effect, as not all the original genetic variation was transferred from the Ardennes to Morvan, and there was not enough resulting genetic variation, at least in allozymes, to be further reduced by multiple establishments of novel populations. In another case of butterfly transfer studied in detail, the transfer of 50 females of the mountain ringlet Erebia epiphron (Knoch, 1783) from Jeseník Mountains to the Krkonoše Mountains, the entire allozyme variation of the source population was transferred to the target area (Schmitt et al., 2005a).

Decrease in heterozygosity of peripheral populations, compared to population in the centre of the distribution of the species, has been previously described for large regions, but not relatively small units, such as a single mountain range. Butterfly examples of the former include Coenonympha hero (Linnaeus, 1761) and C. arcania (Linnaeus, 1761), in which peripheral populations in Sweden display lower heterozygosity than more central populations from Estonia and Russia, and Central Europe, respectively (Cassel \& Tammaru, 2003; Besold et al. 2008), or numerous species with European distributions that survived the last glaciation in refugial areas near the Mediterranean and recolonized Central Europe since the termination of last ice age (e.g., Schmitt et al., 2002; 2005b; Schmitt \& Hewitt, 2004). Studies at regional scales are usually irrelevant in this respect due to the metapopulation processes of local extinction and recolonization taking place from various locations (e.g. Saccheri et al., 1998). In the Morvan case, where colonization took place from two locations, heterozygosity did not correlate with the distance to the nearest release location $(t=-0.13$, $8 \mathrm{df}, P=0.9$, data from Barascud et al., 1999).
The polymorphism level found in the Sumava mountains suggests that it belongs to part of the range recolonised from the Pyrenees rather than from the Balkan range. The high level of polymorphism indicates a continuous survival at a high level of population size (Lande \& Barrowclough, 1987), probably since the end of the last (= Würm) glaciation, some 12000 y BP (cf. Svobodova et al., 2001) or longer (Varga 1977; Varga \& Schmitt, 2008). More notably, the polymorphism seems to be decreasing northwards, as the populations in Ardennes are considerably less polymorphic than those in all southern mountains. Such a pattern is easily explained if we realize that at the height of ice ages, current northern species, such as $P$. eunomia, settled the lowlands of current temperate Europe, as their current northern ranges were covered by ice fields. With the retreat of the glaciers, the northern latitudes were colonized de novo, whereas the more southerly mountain populations were established by short-distance uphill shifts (Varga \& Schmitt, 2008). It is plausible that some northern species lost much of their genetic polymorphism during the longdistance retreats to the North, whilst most of the former genetic diversity was retained in the populations in temperate zone mountains. More species with boreal or boreo-montane distributions should be sampled across latitudinal gradients to test this conjecture.

It should be also noted that reduced genetic diversity through range expansion is generally found in species with narrow ecological requirements (e.g., the butterfly Polyommatus coridon (Poda, 1761): Schmitt et al., 2002; the gall wasp Andricus quercuscalicis (Burgsdorf, 1783): Stone \& Sunnucks, 1993) and/or poor colonization ability [e.g. the ground beetle Carabus auronitens (Fabricius, 1792): Assmann et al., 1994]. These are the result of stepping stone and leptokurtic dispersal power, where long distance dispersal events are very rare, albeit important in the long term (Whitlock, 2001). In contrast, range expansion leads to very little loss of genetic diversity in generalists with wide ecological requirements (e.g., the blue butterfly Polyommatus icarus (Rottemburg, 1775): Schmitt et al., 2003) or high gene flow (e.g. the white butterfly Pieris napi (Linnaeus, 1758): Porter \& Geiger, 1995). The monophagous, wetland-dependent $P$. eunomia clearly belongs to the former group.

In any case, the source population in the Sumava Mts had to be large and viable (Frankel \& Soulé, 1981) prior to the recent expansion, harbouring enough genetic diversity to allow for the steep decline with colonization distance. The fact that no naturalist detected the species prior WWII seems to contradict this presumption, given that the broader area was rather frequently visited by lepidopterists, as pre-war literature documents (e.g. Sterneck, 1929). Still, the intensity of recording was much lower than at present, and the butterfly is on the wing in June, prior to the main vacation season. Meadows in the area were rather intensively used during pre-war years, so that the butterfly was likely surviving in the least accessible areas, such as the complex of bogs in the upper Vltava valley. Other locations have only recently been discov- 
ered, such as in Serbia in 2005 (Jakšić et al., 2007) and the Cantabrian Mountains, Spain in 1983 (Gómez Bustillo et al., 1985).

At present, the butterfly is benefiting from the abandonment of land over 50 years ago. Succession is slow in mountain wet meadows, and includes temporarily blocked stages - the tussocky habitats with high cover of Polygonum bistorta. In terms of population genetics, it can be expected that as individuals continue to disperse between established populations, an equilibrium between drift and migration will be attained, with the effect of isolation by distance caused by multiple founding effects gradually disappearing, as observed in other regions (Nève et al., 2008). Hastings \& Botsford (2006) show that return flights contribute to long-term metapopulation persistence, leading thus to an equilibrium situation.

The currently favourable situation is not permanent, as even the tussocky grasslands suitable for $P$. eunomia would one day succumb to succession of scrub and trees. It follows that while the current state is ideal for the butterfly, some management is necessary in the long term. As the abandoned grasslands are rather species-poor, some conservationists are advocating that they should be restored to a pre-abandonment state (e.g., Matějková et al., 2003). This, however, is a cause for concern. Schtickzelle et al. (2007) showed, in the Belgian Ardennes, that the re-installed cattle grazing, even a relatively light grazing regime of 0.3-0.8 livestock units $\mathrm{ha}^{-1}$, destroys both larval host plants and the tussocks larvae use for basking. This led to decreased recruitment rate and increased emigration as a result of the dramatic decrease in site suitability. Future survival therefore depends on executing management in a mosaic manner, while leaving enough temporarily unmanaged patches, not to threaten the survival of the species, as was unfortunately the case for Colias myrmidone in the White Carpathians (Konvička et al., 2008). We agree with Schtickzelle et al. (2007) that future management needs to maintain meadows in various stages of abandonment in the general landscape, which can be achieved by rotational grazing, temporary cattle exclusions, etc.

In conclusion, the high level of genetic polymorphism retained in this population, and other relict populations found in central and southern European mountains, documents that these populations are not just marginal islets of an otherwise huge distribution area of this species, but represent genuine phylogeographic refugia. The whole area of occurrence enjoys legal protection at present, but continuous survival of this metapopulation will depend on finding a balance between current land abandonment and future active conservation measures. Central localities in the Vltava valley will probably benefit from remaining non-intervention areas. Last but not least, the future of the entire system will depend on how the Šumava Mts will be affected by ongoing climatic change in the coming decades and centuries (Konvička et al., 2003).

ACKNOWLEDGEMENTS. We thank J. Jaroš, E. Lehečka, and K. Spitzer for their help in the collection of specimens, B.
Barascud and C. Moretti for assistance in the laboratory and P. Kepka for help with the map. Z. Fric, Z. Křenová, and E. Meglécz contributed valuable comments on various stages of the work. MK was supported by grants from the Ministry of Education, Youth and Sports of the Czech Republic (LC06073, 6007665801) and from the Entomology Institute (project Z50070508). This paper is dedicated to Professor Henri Descimon, on the occasion of his $75^{\text {th }}$ birthday.

\section{REFERENCES}

ABADJIEv S. 1995: Butterflies of Bulgaria. Vol. 3. Nymphalidae: Apaturinae \& Nymphalinae. Abadjiev, Sofia, 159 pp.

Assmann T., Nolte O. \& Reuter H. 1994: Postglacial colonization of middle Europe by Carabus auronitens as revealed by population genetics (Coleoptera, Carabidae). In Desender K., Dufrêne M., Loreau M., Luff M.L. \& Maelfait J.P. (eds): Carabid Beetles, Ecology and Evolution. Kluwer, Dordrecht, pp. 3-9.

Baguette M., Convié I. \& Nève G. 1996: Male density effect on female spatial behaviour in the butterfly Proclossiana eunomia. Acta Oecol. 17: 225-232.

Barascud B., Martin J.F., Baguette M. \& Descimon H. 1999: Genetic consequences of an introduction-colonization process in an endangered butterfly species. J. Evol. Biol. 12: 697-709.

BARTON N.H. \& WhitLock M.C. 1997: The evolution of metapopulations. In Hanski I. \& Gilpin M.E. (eds): Metapopulation Biology: Ecology, Genetics and Evolution. Academic Press, London, pp. 183-214.

Beneš J., KonvičKa M., Dvořák J., Fric Z., Havelda Z., PavLíčKo A., Vrabec V. \& Weidenhoffer Z. 2002: Butterflies of the Czech Republic: Distribution and Conservation I, II. SOM, Prague, $857 \mathrm{pp}$.

Besold J., Schmitt T., Tammaru T. \& Cassel-Lundhagen A. 2008: Strong genetic impoverishment from the centre of distribution in southern Europe to peripheral Baltic and isolated Scandinavian populations of the pearly heath butterfly. J. Biogeogr. 35: 2090-2101.

CAssel A. \& TAMmaru T. 2003: Allozyme variability in central, peripheral and isolated populations of the scarce heath (Coenonympha hero: Lepidoptera, Nymphalidae): Implications for conservation. Conserv. Genet. 4: 83-93.

Descimon H. 1976: L'acclimatation de lépidoptères: un essai d'expérimentation en biogéographie. Alexanor 9: 195-204.

Descimon H., Zimmermann M., Cosson E., Barascud B. \& Nève G. 2001: Diversité génétique, variation géographique et flux géniques chez quelques Lépidoptères Rhopalocères français. Gen. Sel. Evol. (Suppl. 1) 33: S223-S249.

EBENHÖH J. 1972: Rozšsiŕení perlet'ovce mokřadního (Proclossiana eunomia Esp.) na Šumavě. [The distribution of Proclossiana eunomia in the Šumava Mts.] Zprav. CHKO Šumava 14: 38-39 [in Czech].

Eckert C.G., Samis K.E. \& Lougheed S.C. 2008: Genetic variation across species' geographical ranges: the central-marginal hypothesis and beyond. Mol. Ecol. 17: 1170-1188.

ELton C. 1958: The Ecology of Invasions by Animals and Plants. Methuen, London, $181 \mathrm{pp}$

EXCOFFIER L. \& RAY N. 2008: Surfing during population expansions promotes genetic revolutions and structuration. Trends Ecol. Evol. 23: 347-351.

Felsenstein J. 1993: CONTML, Gene Frequencies and Continuous Characters Maximum Likelihood Method. Version 3.5c. University of Washington, Washington, $5 \mathrm{pp}$.

Frankel O.H. \& SoulÉ M.E. 1981: Conservation and Evolution. Cambridge University Press, Cambridge, 327 pp. 
GiLPIN M. 1991: The genetic effective size of a metapopulation. Biol. J. Linn. Soc. 42: 165-175.

Gómez Bustillo M.R., Odriozola I. \& Eizaguirre S. 1985: Nueva subspecie de Proclossiana eunomia (Esp.[1799]) (Lep. Nymphalidae). Shilap Revista. Lepid. 13(49): 69-71.

Goudet J. 2005: Hierfstat, a package for R to compute and test hierarchical F-statistics. Mol. Ecol. Notes 5: 184-186.

Habel J.C. \& Assmann T. (eds) 2009: Survival on Changing Climate - Phylogeography and Conservation of Relict Species. Springer, Heidelberg.

Hanski I. 1999: Metapopulation Ecology. Oxford University Press, Oxford, $328 \mathrm{pp}$

Hastings A. \& Botsford L.W. 2006: Persistence of spatial populations depends on returning home. Proc. Nat. Acad. Sci. USA 103: 6067-6072.

Havel L. 1970: Z bionomie perlet'ovce mokřadního (Proclossiana eunomia Esper 1797). [On the life history of the butterfly Proclossiana eunomia.]. Sborník Jihočeského muzea v Českých Budějovicích 10: 114-117 [in Czech].

Hebert P.D.N. \& Beaton M.J. 1993: Methodologies for Allozyme Analysis Using Cellulose Acetate Electrophoresis. Helena Laboratories, Beaumont, TX, 32 pp.

JAKŠIĆ P., van SWAAY C. \& ĐuRIĆ M. 2007: Boloria eunomia (Esper, 1799): a new species for Serbia (Nymphalidae). Nota Lepid. 30: 64-70.

KonvičKa M., Maradová M., Beneš J., Fric Z. \& KepKa P. 2003: Uphill shifts in distribution of butterflies in the Czech Republic: effects of changing climate detected on a regional scale. Global Ecol. Biogeogr. 12: 403-410.

KonvičKa M., Beneš J., Č́̇̌̌̌K O., KopeČEK F., KonvičKa O. \& VíŤAz L. 2008: How too much care kills species: Grassland reserves, agrienvironmental schemes and extinction of Colias myrmidone (Lepidoptera: Pieridae) from its former stronghold. J. Insect Conserv. 12: 519-525.

Krahulec F., BlažKová D., Balátová-TuláčKová E., Štursa J., PeChÁČKovÁ S. \& FABŠICOVÁ M. 1997: Meadows in the Krkonoše Mts - plant communities and their dynamics. Opera Corcontica 33: 3-250.

LANDE R. \& BARRowClough G.L. 1987: Effective population size, genetic variation, and their use in population management. In Soulé M.E. (ed.): Viable Populations for Conservation. Cambridge University Press, Cambridge, pp. 87-123.

MatěJKová I., van Diggelen R. \& Prach K. 2003: An attempt to restore a central European species-rich mountain grassland through grazing. Appl. Veg. Sc. 6: 161-168.

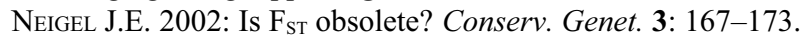

NÈVE G. 2009: Population genetics of butterflies. In Settele J., Shreeve T.G., Dennis R.L.H. \& Van Dyck H. (eds): The Ecology of Butterflies in Europe. Cambridge University Press, Cambridge.

Nève G., Barascud B., Hughes R., Aubert J., Descimon H., Lebrun P. \& Baguette M. 1996: Dispersal, colonization power and metapopulation structure in the vulnerable butterfly Proclossiana eunomia (Lepidoptera, Nymphalidae). $J$. Appl. Ecol. 33: 14-22.

Nève G., Barascud B., Descimon H. \& Baguette M. 2000: Genetic structure of Proclossiana eunomia populations at the regional scale (Lepidoptera, Nymphalidae). Heredity 84: $657-666$.

Nève G., Barascud B., Descimon H. \& Baguette M. 2008: Gene flow rise with habitat fragmentation in the bog fritillary butterfly (Lepidoptera, Nymphalidae). BMC Evol. Biol. 8: e84.

PavlíčKo A. 1996a: Rozšíření perlet’ovce mokřadního (Proclossiana eunomia) na Šumavě a jeho vztah $k$ hospodaření v krajině. [The distribution of Proclossiana eunomia in the Šumava
Mts in relation to landscape management.] Silva Gabreta 1: 197-202 [in Czech].

PavlíčKo A. 1996b: Výskyt perlet'ovce mokřadního (Proclossiana eunomia Esp.) a perlet'ovce severního (Boloria aquilonaris St.) na Šumavě. [On the distribution of Proclossiana eunomia and Boloria aquilonaris in the Šmava Mts.] Zlatá Stezka, Sbor. Prach. Muz. 3: 311-323 [in Czech].

Porter A.H. \& Geiger H. 1995: Limitations to the inference of gene flow at regional geographic scales - an example from the Pieris napi group (Lepidoptera: Pieridae) in Europe. Biol. J. Linn. Soc. 54: 329-348.

R Development Core Team 2004. $R$ : A Language and Environment for Statistical Computing. R Foundation for Statistical Computing, Vienna. Available from http://www.R-project.org (accessed January 2007).

RAYMOND M. \& Rousset F. 1995: An exact test for population differentiation. Evolution 49: 1280-1283.

ReIchl E.R. 1992: Verbreitungsatlas der Tierwelt Österreichs. Band 1: Lepidoptera - Diurna, Tagfalter. Forschunginstitut für Umweltinformatik, Linz, $106 \mathrm{pp}$.

Richardson B.J., Baverstock P.R. \& Adams M. 1986: Allozyme Electrophoresis. Academic Press, Sydney, 410 pp.

Rousset F. 2004: Genetic Structure and Selection in Subdivided Populations. Princeton University Press, Princeton, 264 pp.

RouSSET F. 2008: GENEPOP'007: a complete re-implementation of the GENEPOP software for Windows and Linux. Mol. Ecol. Res. 8: 103-106.

Saccheri I., KuUssaari M., Kankare M., Vikman P., Fortelius W. \& HANSKI I. 1998: Inbreeding and extinction in a butterfly metapopulation. Nature 392: 491-494.

Schmitt T. \& HewitT G.M. 2004: The genetic pattern of population threat and loss: a case study of butterflies. Mol. Ecol. 13: 21-31.

Schmitt T., Giessl A. \& Seitz A. 2002: Postglacial colonisation of western Central Europe by Polyommatus coridon (Poda, 1761) (Lepidoptera: Lycaenidae): evidence from population genetics. Heredity 88: 26-34.

Schmitt T., Giessl A. \& Seitz A. 2003: Did Polyommatus icarus (Lepidoptera: Lycaenidae) have distinct glacial refugia in southern Europe? Evidence from population genetics. Biol. J. Linn. Soc. 80: 529-538.

Schmitt T., ČížEK O. \& KonvičKa M. 2005a: Genetics of a butterfly relocation: large, small and introduced populations of the mountain endemic Erebia epiphron silesiana. Biol. Cons. 123: $11-18$.

Schmitt T., Varga Z. \& Seitz A. 2005b: Are Polyommatus hispana and Polyommatus slovacus bivoltine Polyommatus coridon (Lepidoptera: Lycaenidae)? The discriminatory value of genetics in taxonomy. Org. Divers. Evol. 5: 297-307.

Schtickzelle N., Mennechez G. \& Baguette M. 2006: Dispersal depression with habitat fragmentation in the bog fritillary butterfly. Ecology 87: 1057-1065.

Schtickzelle N., Turlure C. \& Baguette M. 2007: Grazing management impacts on the viability of the threatened bog fritillary butterfly Proclossiana eunomia. Biol. Conserv. 136: 651-660.

SimOnSEN T.J. 2005: Boloria phylogeny (Lepidoptera: Nymphalidae): tentatively reconstructed on the basis of male and female genitalia morphology. Syst. Entomol. 30: 653-665.

SimONSEN T.J. 2006: Fritillary phylogeny, classification, and larval host plants: reconstructed mainly on the basis of male and female genitalic morphology (Lepidoptera: Nymphalidae: Argynnini). Biol. J. Linn. Soc. 89: 627-673.

SLATKIN M. 1993: Isolation by distance in equilibrium and nonequilibrium populations. Evolution 47: 264-279. 
Sterneck J. 1929: Prodromus der Schmetterlingsfauna Böhmens. Selbstverlag, Karlsbad, 278 pp.

Stone G.N. \& Sunnucks P. 1993: Genetic consequences of an invasion through a patchy environment - the cynipid gallwasp Andricus quercuscalicis (Hymenoptera: Cynididae). Mol. Ecol. 2: 251-268.

Stone G.N., Atkinson R.J., Brown G., Rokas A. \& Csoka G. 2003: The population genetic consequences of range expansion: oak gallwasps as a model system. In Hails R.S., Beringer J.E. \& Godfray H.C.J. (eds): Genes in the Environment. Blackwell, Oxford, pp. 46-62.

Summerville K.S. 2008: Species diversity and persistence in restored and remnant tallgrass prairies of North America: a function of species' life history, habitat type, or sampling bias? J. Anim. Ecol. 77: 487-494.

Svobodova H., Reille M. \& Goeury C. 2001: Past vegetation dynamics of Vltavsky luh, upper Vltava river valley in the Sumava mountains, Czech Republic. Veg. Hist. Archaeobot. 10: $185-199$.

Tuzov V.K. \& Bozano G.C. 2006: Guide to the Butterflies of the Palearctic Region. Nymphalidae, Part II, Tribe Argynnini: Boloria, Proclossiana, Clossiana. Omnes Artes, Milano, $72 \mathrm{pp}$.

VARGA Z. 1977: Das Prinzip der areal-analytischen Methode in der Zoogeographie und die Faunenelemente-Einteilung der europaäischen Tagschmetterlinge (Lepidoptera: Diurna). Acta Biol. Debrecina 14: 223-285.

VARGA Z.S. \& SchmitT T. 2008: Types of oreal and oreotundral disjunctions in the western Palearctic. Biol. J. Linn. Soc. 93: 415-430.
Verity R. 1950: Le Farfalle Diurne d'Italia. Vol. 4. Marzocco, Firenze, $380 \mathrm{pp}$.

WeIr B.S. \& Cockerham C.C. 1984: Estimating F-statistics for the analysis of population structure. Evolution 38: $1358-1370$.

WeIss D. 1966: Zpráva o výskytu perlet’ovce mokřadního (Clossiana aphirape Hbn.) na Šumavě (Rhopalocera, Nymphalidae). [Record of the butterfly Clossiana aphirape in the Šumava Mts.] Zprav. Čs. Spol. Entomol. ČSAV 2: 103-104 [in Czech].

Weiss D. 1967: Perlet'ovec Proclossiana eunomia Esper, 1797 (C. aphirape Hübner, 1799) v Československu (Lepidoptera, Nymphalidae). [The fritillary Proclossiana eunomia Esper, 1797 (C. aphirape Hübner, 1799) in Czechoslovakia.] Cas. Nár. Muz. Odd. Př́rr. 136: 195-200 [in Czech].

Weiss D. 1972: Perlet'ovec severský (Boloria aquilonaris Stichel, 1908) a jeho rozšíření v Československu (Lepidoptera, Nymphalidae). [The fritillary Boloria aquilonaris Stichel, 1908 and its distribution in Czechoslovakia (Lepidoptera, Nymphalidae).] Čas. Nár. Muz. Odd. Př́rr. 141: 33-37 [in Czech].

WhitLock M.C. 2001: Dispersal and the genetic properties of metapopulations. In Clobert J., Danchin E., Dhondt A.A. \& Nichols J.D. (eds): Dispersal. Oxford University Press, Oxford, pp. 273-282.

Whitlock M.C. \& McCauley D.E. 1999: Indirect measures of gene flow and migration: $\mathrm{F}_{\mathrm{ST}} \neq 1 /(4 \mathrm{Nm}+1)$. Heredity $\mathbf{8 2}$ : $117-125$.

Received September 3, 2008; revised October 20, 2008 